\section{Intercropped Watermelon for Weed Suppression in a Low-input Organic System}

\author{
Jose G. Franco ${ }^{1,5,6}$, Stephen R. King ${ }^{2}$, Joseph G. Masabni ${ }^{3}$, \\ and Astrid Volder ${ }^{4}$
}

AdDITIONAL INDEX wORDs. Citrullus lanatus, intercropping, canopy density, leaf area index

SUMMARY. The inclusion of a smother crop used as a cash crop in an intercropping system may be an effective cultural control strategy for the management of weeds in organic production systems. In addition, a multilayered canopy created when intercropping species with different growth forms may limit germination cues for weed seeds and can allow for a more efficient utilization of resources that reduce competition to target crops from weeds. Watermelon (Citrullus lanatus) was evaluated for its ability to reduce weeds in a low-input organic system in Texas when planted alone or in various intercropping combinations that also included peanut (Avachis bypogaea), okra (Abelmoschusesculentus), cowpea (Vigna unguiculata), and hot pepper (Capsicum annuиm). Watermelon significantly reduced total weed biomass when planted in monoculture and in all intercropping combinations compared with peanut, okra, cowpea, and pepper monocultures in year 1 of the 2 -year study. Total weed biomass was reduced by $81 \%, 83 \%, 88 \%$, and $92 \%$ in treatments containing watermelon on average as compared with pepper, peanut, okra, and cowpea grown in monoculture, respectively. Less effective weed suppression was obtained with watermelon in year 2. Pepper grown in monoculture had significantly higher weed biomass than all other treatments in year 2 . Broadleaf weeds were effectively suppressed across all intercropping treatments in year 1 , but nutsedges (Cyperus sp.) were consistently reduced both years, particularly when compared with monocrops with small leaf area such as pepper. The three and four species intercropping combinations consistently had high leaf area index (LAI) values, whereas pepper monoculture had significantly lower LAI values than all other treatments except for cowpea monoculture. There was a significant negative relationship between LAI and total weed biomass $33 \mathrm{~d}$ after last planting $(r=$ $-0.51, P<0.01)$. There was a significant negative relationship between total weed biomass and total fruit yield in year $1(r=-0.64, P<0.01)$ but no significant relationship in year 2 . Although findings were inconsistent in year 2 because of changes in precipitation amounts and in relative planting dates, these findings suggest that incorporating a multifunctional intercropping system that includes a low-growing vining crop such as watermelon or at least an architecturally complex mixture can optimize canopy density to reduce weed pressure from resilient perennial weeds such as nutsedge. This may offer organic producers another management tool for the control of perennial weeds.

$\mathrm{W}$ Teed management in agricultural systems is the single greatest input of labor and chemicals (Dayan et al., 2011; Wang et al., 2009). Weeds compete with the crops for moisture, nutrients, and light. Therefore, weeds, more so than any other pest, have the greatest adverse impact on crop yields (Dayan et al., 2011). Yield losses from $40 \%$ to $80 \%$ have been cited because of weed populations left unmanaged and outcompeting cash crops for resources (Akobundu, 1987; Karlen et al., 2002). The cost of weed control, along with the associated yield losses due to weed competition, has been estimated at more than \$15 billion annually in developed nations (Buhler, 2003). Because of their highly effective mode of action and relative low cost, synthetic herbicides have been a reliable tool for weed control in conventional systems (Dayan et al., 2011; den Hollander et al., 2007). However, the increasing demand for organic food and concerns over the potential detrimental effects these herbicides have on human health and on the environment have driven demand for nonchemical alternatives for managing and controlling weed populations (Dayan et al., 2009; den Hollander et al., 2007; Webber et al., 2014).

In organic systems, herbicide options for weed control are limited (Peruzzi et al., 2007). This creates a challenge for organic farmers and is the largest obstacle for producers considering transitioning from conventional production systems (Barberi, 2002). Weeds are an even bigger problem in low-input systems and, in particular, with slow-growing vegetable crops such as pepper that are inferior competitors (den Hollander et al., 2007; Isik et al., 2009). This is especially problematic when it comes to managing perennial weeds (Wedryk et al., 2012). Organic farmers tend to rely on physical, cultural, and mechanical techniques such as mulching, smother cover crops, cultivation, and direct manual weeding to suppress weeds (Bilalis et al., 2010; Isik et al., 2009; Mulvaney et al., 2011).

Intercropping is a potentially effective cultural control strategy for weeds in organic production systems. Intercropping is the practice of growing two or more crops within the same area such that there is biological and agronomic interaction (Mohler and Stoner, 2009; Vandermeer, 1989). Often used as a way to introduce biodiversity into agroecosystems (Unlu et al., 2010), intercropping can also be used in conjunction with other practices such as soil solarization and cover cropping as a management strategy for reducing pest pressure and suppressing the spread of disease, particularly in organic and low-input farming systems.

The ability of the cash crop to outcompete weeds is enhanced in intercropping systems through an increase in resource capture by the desired species which reduces the availability of resources such as light, water, and nutrients to weeds (Barberi, 2002; Baumann et al., 2002; Saudy, 2015), as well as through allelopathic

\begin{tabular}{llll}
\hline $\begin{array}{l}\text { Units } \\
\text { To convert U.S. to SI, } \\
\text { multiply by }\end{array}$ & U.S. unit & SI unit & $\begin{array}{l}\text { To convert SI to U.S., } \\
\text { multiply by }\end{array}$ \\
\hline 0.3048 & $\mathrm{ft}$ & $\mathrm{m}$ & 3.2808 \\
0.0929 & $\mathrm{ft}^{2}$ & $\mathrm{~m}^{2}$ & 10.7639 \\
2.54 & inch $(\mathrm{es})$ & $\mathrm{cm}$ & 0.3937 \\
25.4 & inch $(\mathrm{es})$ & $\mathrm{mm}$ & 0.0394 \\
1.1209 & $\mathrm{lb} / \mathrm{acre}$ & $\mathrm{kg} \cdot \mathrm{ha}^{-1}$ & 0.8922 \\
$\left({ }^{\circ} \mathrm{F}-32\right) \div 1.8$ & ${ }^{\circ} \mathrm{F}$ & ${ }^{\circ} \mathrm{C}$ & $\left({ }^{\circ} \mathrm{C} \times 1.8\right)+32$
\end{tabular}


interactions (Iqbal et al., 2007). However, the extent of competitive interactions depend on factors such as crop geometry, canopy architecture, planting density, planting time, and crop growth rate (Isik et al., 2009; Keating and Carberry, 1993). Plants with different forms can be intercropped to create a more complex multilayer system that mimics natural ecosystems (Denevan, 1995). The ability of a multilayer intercropping system to suppress weed growth is typically owed to a reduction in light transmittance due to an increase in canopy density (Baumann et al., 2002). Aboveground plant biomass has been found to be positively correlated with the interception of solar radiation by the canopy (Kiniry et al., 2005). For example, Bilalis et al. (2010) found that a maize (Zea mays)-legume intercrop led to higher canopy cover and more efficient use of solar energy, thereby increasing weed suppression. Therefore, the ability of complex multilayered mixed cropping systems to maximize canopy density and increase radiation interception makes them a potentially useful tool for weed management in organic and low-input farming systems (Saudy, 2015).

We previously reported that an increase in plant functional diversity led to overyielding of harvestable fruit; i.e., increased overall production per unit land area (Franco et al., 2015). Although it is likely that several factors may have contributed to overyielding in mixed cropping systems, it is possible that weed suppression may have played a key role in our observations. In this article, we evaluate the ability of watermelon to reduce weed biomass and explore the relationships between

\footnotetext{
We thank Southern Sustainable Agriculture Research and Education (SARE) for funding this research (Grant\# GS11-108); and Dominique Conrad, Romeo Montalvo, and Kyle Harrison for their assistance with data collection; and all those who provided input during the design phase of this study.

${ }^{1}$ Department of Ecosystem Science and Management, Texas A\&M University, HFSB 305, 2138 TAMU, College Station, TX 77843

${ }^{2}$ Millican Farms, LLC, Millican, TX 77866

${ }^{3}$ Department of Horticultural Sciences, Texas A\&M AgriLife Research \& Extension Center at Overton, 1710 North FM 3053, Overton, TX 75684

${ }^{4}$ Department of Plant Sciences, University of California, Davis, One Shields Avenue, Davis, CA 95616

${ }^{5}$ Current address: Northern Great Plains Research Laboratory, U.S. Department of Agriculture-Agricultural Research Service, P.O. Box 459, Mandan, ND 58554.

${ }^{6}$ Corresponding author. E-mail: jose.g.franco.jr@ gmail.com.
}

https://doi.org/10.21273/HORTTECH03940-17 weed suppression, yields, aboveground plant biomass, and LAI. The primary objective of this study was to test the ability of watermelon and diverse intercropping systems to suppress weeds in a low-input organic production system. We hypothesized that cropping systems consisting of watermelon and more architecturally complex multilayer canopies would reduce weed pressure as compared with monocultures; i.e., less complex systems. We also hypothesized that this reduction in weed biomass would be the result of increased leaf area and aboveground plant biomass intercepting solar radiation. The species used in this study were peanut, watermelon, okra, cowpea, and pepper.

\section{Materials and methods}

STUDY SITE AND EXPERIMENTAL DESIGN. This study was conducted on the Texas A\&M University's Horticulture Farm, Bryan, TX (lat. $30^{\circ} 37^{\prime} \mathrm{N}$, long. $96^{\circ} 22^{\prime} \mathrm{W}$ ), in 2011 and 2012. Average maximum and minimum monthly air temperatures during the growing season May to October ranged from 14 to $42^{\circ} \mathrm{C}$ and $\mathrm{l}$ to $27^{\circ} \mathrm{C}$, respectively, in 2011 and 17 to $41{ }^{\circ} \mathrm{C}$ and 5 to $26{ }^{\circ} \mathrm{C}$, respectively, in 2012 (Fig. 1). For the 2011 experimental growing season (1 Aug. through 31 Oct.), total precipitation was $95 \mathrm{~mm}$, whereas there was close to double that precipitation in the 2012 experimental growing season (21 June through 31 Oct.), i.e., $185 \mathrm{~mm}$ (National Oceanic and Atmospheric Administration, 2018). There were also more frequent precipitation events in 2012, particularly at the time of planting. Total water input for 2011 and 2012 was 244 and $483 \mathrm{~mm}$, respectively, taking into account supplemental irrigation that was applied several times during each growing season.

Described in more detail in Franco et al. (2015), the study design consisted of a randomized complete block with three replications, five intercropping treatments, and five controls. The controls were monocultures of the five component species, peanut, mini watermelon, okra, cowpea, and pepper, which were selected primarily based on their heat tolerance and desired architecture and function (Table 1 ). The five treatments were a within-row intercropping system of 1 ) peanut and watermelon $\left.\left(W_{\mathrm{pw}}\right), 2\right)$ peanut, watermelon, and okra $\left.\left(W_{\text {pwo }}\right), 3\right)$ peanut, watermelon, okra, and cowpea $\left(W_{\text {pwoc }}\right)$, $4)$ all five control species $\left(W_{\text {all }}\right)$, and 5) a strip intercropping system of peanut and watermelon consisting of alternating single rows $\left(S_{\mathrm{pw}}\right)$. Crops were planted at uniform densities $(30 \mathrm{~cm}$ individual plant spacing) regardless of cropping system and in a staggered double-row pattern on $90-\mathrm{cm}$-wide raised beds with $30-\mathrm{cm}$ row spacing (total plot size, $4 \times 5 \mathrm{~m}$ ). The strip intercropping system was also planted on raised beds with two crop rows, one row of watermelon and one row of peanut. A total of four raised beds per plot were planted. Densities were based on methodologies recommended by Jeavons (2006), whereby the mean spacing requirement for all component crops was used, and using minimum spacing requirements outlined in the Texas Vegetable Growers Handbook (Masabni and Dainello, 2009).

In year 1 , peanut was direct seeded on 1 Aug. 2011 and watermelon was direct seeded $\approx 1$ week later on 7 Aug. Okra and cowpea were direct seeded on 14 and 15 Aug., respectively. Sevencentimeter-tall pepper plants were transplanted on 18 Aug. Reseeding of peanut, okra, cowpea, and watermelon as well as pepper transplant replacement continued through the last week of August. Peanut and cowpea were inoculated with Bradyrbizobium inoculant (Vault SP; Becker Underwood, Ames, IA) during planting as this field had not previously been inoculated with rhizobia.

Planting dates were altered in year 2 to allow for peanut harvest and minimize competition with watermelon in year 2 . Peanut and okra were direct seeded on 21 and 22 June 2012 , respectively. Cowpea was direct seeded $\approx 1$ week later on 27 June. Peanut and cowpea were again inoculated with Bradyrhizobium inoculant. Seven-centimeter-tall pepper plants were transplanted on 3 July. Watermelon was direct seeded on 12 July. Reseeding of peanut, okra, cowpea, and watermelon as well as pepper transplant replacement continued through the last week of July.

SAMPLING AND ANALYSIs. Multifunctional intercropping effects on weed suppression were assessed by hand harvesting aboveground weed biomass from the center $2 \mathrm{~m}$ of the 
(A)

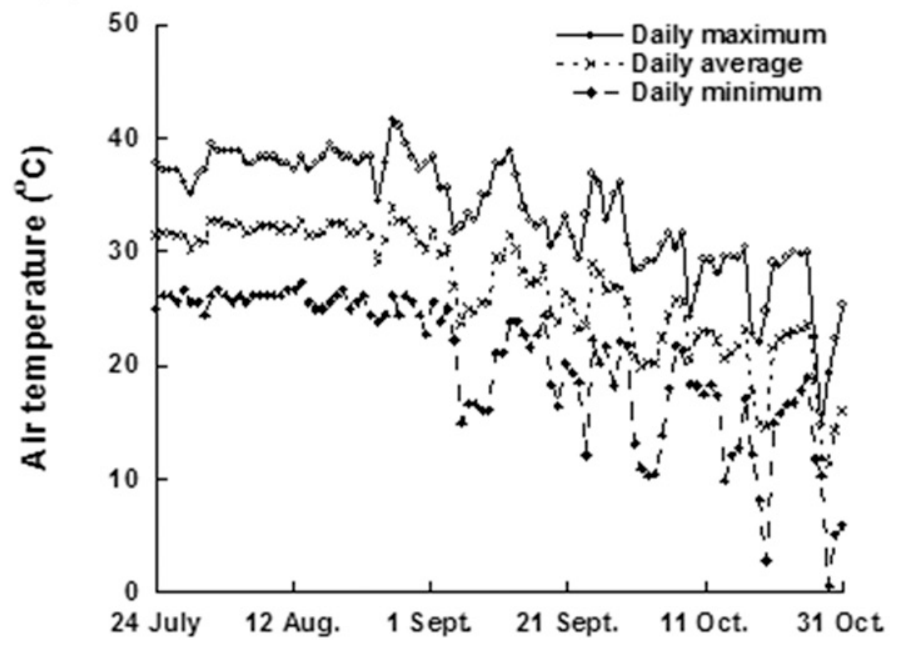

(B)

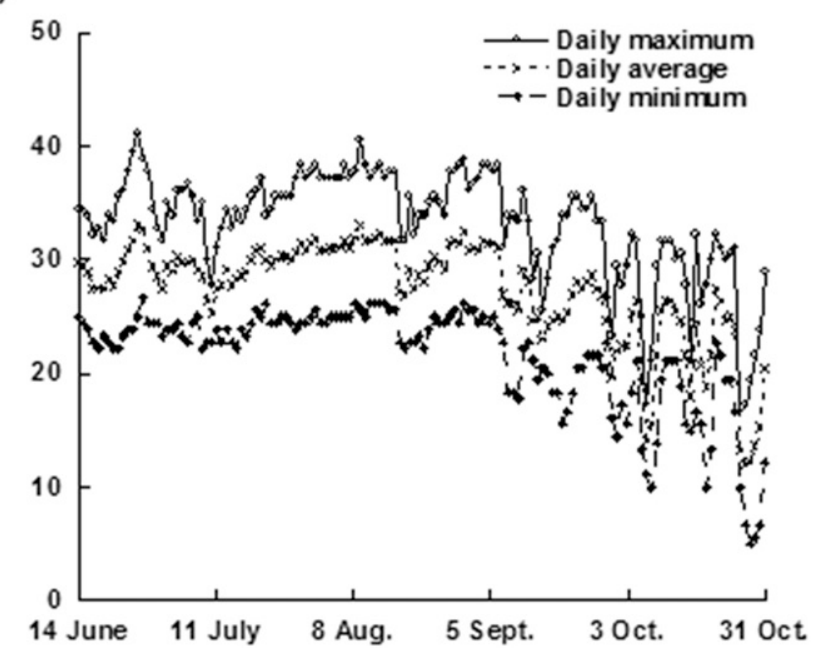

Fig. 1. Daily maximum, daily average, and daily minimum air temperatures for the (A) 2011 and (B) 2012 growing seasons. Dashed vertical lines indicate the date of first planting for each growing season; $\left({ }^{\circ} \mathrm{C} \times 1.8\right)+32={ }^{\circ} \mathrm{F}$.

Table 1. Component crops and their potential primary and secondary contributions to the system and plant growth habit (architecture).

\begin{tabular}{|c|c|c|c|c|c|}
\hline Crop & Variety & Family & Function & Architecture & Reference \\
\hline Peanut & Tamspan 90 & Fabaceae & $\begin{array}{l}\text { Nitrogen fixation and } \\
\text { smother crop }\end{array}$ & Low/mid growth form & Baughman et al. (2007) \\
\hline Watermelon & TAMU Mini ${ }^{\mathrm{z}}$ & Cucurbitaceae & $\begin{array}{l}\text { Smother crop and } \\
\text { shading }\end{array}$ & Low growth form & Masabni and Dainello (2009) \\
\hline Okra & Clemson spineless & Malvaceae & $\begin{array}{l}\text { Pollinator attractant and } \\
\text { structural support }\end{array}$ & Tall growth form & Masabni and Dainello (2009) \\
\hline Pepper & Jalapeño/serrano & Solanaceae & Pest barrier & Mid growth form & Masabni and Dainello (2009) \\
\hline
\end{tabular}

${ }^{\mathrm{z}}$ Unreleased variety.

center raised bed row to avoid edge effects. Total weed sampling area was $0.9 \times 2.0 \mathrm{~m}$. Initial weed control across the entire plot was performed until seedlings reached a height of $\approx 3$ inches. From that point on, weed control was performed only on areas outside the designated sampling area as necessary. Within the sampling area, weed harvesting was conducted every 2-3 weeks through the end of harvest in both 2011 and 2012. Weed biomass was separated into three categories: grasses, sedges, and broadleaf weeds. The samples were then rinsed to remove excess soil and oven-dried for $48 \mathrm{~h}$ or to a constant weight at $38{ }^{\circ} \mathrm{C}$. Total dry aboveground weed biomass was then converted from plot scale to kilograms per hectare. Total weed biomass and yield data (methodologies described in Franco et al., 2015) were used to explore the relationship between these two parameters.
To assess the effects of canopy density on weed suppression, aboveground plant biomass and LAI data were collected in year 2 of the experiment. Plants were harvested from one row of each replication in Sept. 2012 [69-72 d after planting of the last crop (DALP)] to assess total and per species aboveground plant biomass. Fruit and pods were omitted so that plant biomass samples included only leaf and stem material. LAI, or the total leaf area per unit ground area [square meters of leaf area per square meter of soil surface (Schieving and Poorter, 1999)], was measured in 2012 using a ceptometer (AccuPAR; Decagon Scientific, Pullman, WA) placed at a right angle between crop rows and just aboveground level. Measurements were taken on 14 and 24 Aug. and 13 Sept. (33, 43, and 63 DALP) and only when conditions were sunny. Three readings were consistently taken toward the center of each plot between
1200 and $1400 \mathrm{HR}$ and compared with readings from an adjacent open field. An on-site weather station (EZ Mount GroWeather; Davies Instruments, Hayward, CA) recorded air temperature and relative humidity.

All data were analyzed using analysis of variance or correlation analysis in JMP software (version 11.0 for Windows; SAS Institute, Cary, NC). The Shapiro-Wilk goodness-of-fit test was used to assure assumptions of normality were met. When these assumptions were not met, log transformations were used and the model with the highest $r^{2}$ value was accepted. Where a significant $F$-test was observed $(P \leq 0.05)$, mean separations were conducted using Fisher's least significant difference test. Simple correlation analysis was used to explore relationships between total plot yield, aboveground plant biomass (year 2 only), land equivalent ratio, and aboveground weed biomass. 


\section{Results}

WeEd BIOMAss. Total aboveground weed biomass was significantly reduced in 2011 in all intercropping combinations containing watermelon and in watermelon monoculture when compared with all other monocultures (Fig. 2A). Weed biomass was less than $130 \mathrm{~kg} \cdot \mathrm{ha}^{-1}$ in combinations containing watermelon, whereas weed biomass was 500,564 , 808 , and $1201 \mathrm{~kg} \cdot \mathrm{ha}^{-1}$ in peanut, pepper, okra, and cowpea monocrops, respectively. On average, the presence of watermelon reduced weed biomass by $81 \%, 83 \%, 88 \%$, and $92 \%$ compared with peanut, pepper, okra, and cowpea monocultures, respectively. However, in 2012, watermelon did not suppress weed growth with the same efficiency (Fig. $2 \mathrm{~B})$. Total weed biomass was significantly higher in the pepper monocrop at $1225 \mathrm{~kg} \cdot \mathrm{ha}^{-1}$ as compared with most other treatments. However, because of high variability, no statistically significant differences were detected between pepper monocrop, $S_{\mathrm{pw}}$, and $W_{\text {pwoc }}$. There were no significant differences between the cowpea, peanut, and okra monocrops and intercropping combinations that contained watermelon in 2012.

When broken down by weed type, the most prevalent broadleaf weeds were carpetweed (Mollugo verticillata), common purslane (Portulaca oleracea), and spurge (Euphorbia sp.) (data not shown). There was significantly more broadleaf weed biomass in cowpea, peanut, and okra monocultures in $2011,306,332$, and $420 \mathrm{~kg} \cdot \mathrm{ha}^{-1}$, respectively, compared with most other cropping combinations (Fig. 3A). As with total weed biomass, watermelon monoculture had the least amount of broadleaf weed biomass at $4 \mathrm{~kg} \cdot \mathrm{ha}^{-1}$. In 2012, there were no significant differences between cropping systems although the watermelon-peanut strip intercropping combination and monocropped pepper had the most broadleaf weeds, 400 and $405 \mathrm{~kg} \cdot \mathrm{ha}^{-1}$, respectively (Fig. 3B). The most prevalent sedges were yellow nutsedge (Cyperus esculentus) and purple nutsedge (Cyperus rotundus) (data not shown). There was significantly more sedge weed biomass in monocropped cowpea in 2011 as compared with watermelon monoculture, $W_{\mathrm{pw}}, S_{\mathrm{pw}}, W_{\mathrm{pwo}}$, and $W_{\text {all }}$ (Fig. 3C). Although higher than all treatments containing watermelon, sedge biomass in pepper monoculture was only statistically significantly higher than $S_{\mathrm{pw}}, W_{\mathrm{pwo}}$, and $W_{\text {all }}$. Sedges were significantly higher in pepper monoculture in 2012 as compared with all other monocrops and mixture combinations (Fig. 3D). The most prevalent weedy grasses were crabgrass (Digitaria sp.) and bermudagrass (Cynodon dactylon) (data not shown). Grass biomass followed similar trends as sedge in 2011 with cowpea having significantly more grass biomass than watermelon monocrop, $S_{\text {pw }}, W_{\text {pwoc }}$, and $W_{\text {all }}$, but no statistically significant differences were detected in grass biomass in 2012 (Fig. $3 \mathrm{E}$ and $\mathrm{F})$.

WEED BIOMASS YIELD. In 2011 , there was a significant negative relationship between total weed biomass and total yield $[r=-0.64, P<$ 0.01 (Fig. 4A)]. As total weed biomass decreased, there was an increase in total fruit yield; however, in 2012, there was no significant relationship between total weed biomass and total yield (Fig. 4B). When broken down by weed type, similar relationships were found in 2011 when correlation analyses were conducted with broadleaf weed $(r=-0.44, P=0.02)$, sedge weed $(r=-0.58, P<0.01)$, and grass weed $(r=-0.55, P<0.01)$ biomass with total crop yield (data not shown). No significant relationships were found between broadleaf, grass, and sedge weeds and total crop yield in 2012 .

Aboveground plant biomass AND LAI. A significant relationship between total aboveground plant biomass and total weed biomass was not found $(P=0.13)$. Okra was the dominant crop in 2012, accounting for $88 \%$ of the total aboveground plant biomass $[P<0.01$ (data not shown)]. However, okra plant biomass was not an effective predictor of total weed biomass $[P=0.29$ (data not shown)]. When analyzed by weed type, there was as a significant negative linear relationship between total aboveground plant biomass and sedge weed biomass $[r=-0.46, P=0.01$ (Fig. 5B)], but there was no significant relationship between broadleaf or grass weed biomass and plant biomass (Fig. $5 \mathrm{~A}$ and $\mathrm{C}$ ).

LAI measurements taken 33 DALP were not significantly different between any monocrops and intercropping combinations (Fig. 6A). However, $10 \mathrm{~d}$ later, cropping treatments began to differentiate themselves. Cowpea and pepper monocultures had significantly lower LAI values than all other monocrops and intercropping combinations (Fig. 6B). Okra monoculture and the three and four species intercropping combinations, $W_{\text {pwo }}$ and $W_{\text {pwoc }}$, had some of the largest LAI values $(>2.0)$. Twenty days later at 63 DALP, peanut had formed a full-dense canopy and had significantly higher LAI than all other monocultures, whereas pepper continued to have the lowest LAI [3.0 for peanut, 2.1 for okra, 1.7 for watermelon, 1.3 for cowpea, and 0.4 for pepper (Fig. 6C)]. The $W_{\mathrm{pw}}$ intercropping combination also increased in canopy with the maturity of peanut with an LAI of 2.5, although no statistical comparisons were made between sampling dates. The intercropping combinations of $W_{\text {pwo }}$ and $W_{\text {pwoc }}$ had consistently high LAI values throughout all measurement dates. Little change in LAI between 43 and 63 DALP also indicates that the canopy had almost reached full maturity at 43 DALP.

There was a significant positive linear relationship between total aboveground plant biomass and LAI for all three measurement dates $[r=$ 0.36-0.64, significant at $P=0.05$ (data not shown)]. There was a significant negative relationship between LAI and total weed biomass at 33 $\operatorname{DALP}(r=-0.51, P<0.01)$, but there were no significant relationships at 43 and 63 DALP $(P=0.09$ and $P=0.15$, respectively) (Fig. 7A-C).

\section{Discussion and conclusion}

Although the term "smother" crop is typically applied to cover crops not typically harvested for food consumption, we found that a cash crop such as watermelon has the potential to be an effective smother crop. Because watermelon performance was greatly reduced in year 2 of the study, its ability to perform as an effective smother crop was greatly diminished. However, it should be noted that more frequent and increased total precipitation in 2012 may have also created an environment more conducive for weeds and reduced competition with component crops, further diminishing the benefits of using 


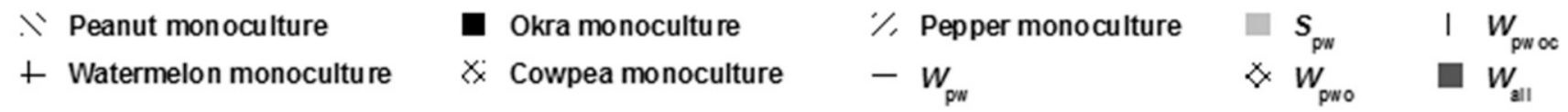

(A)

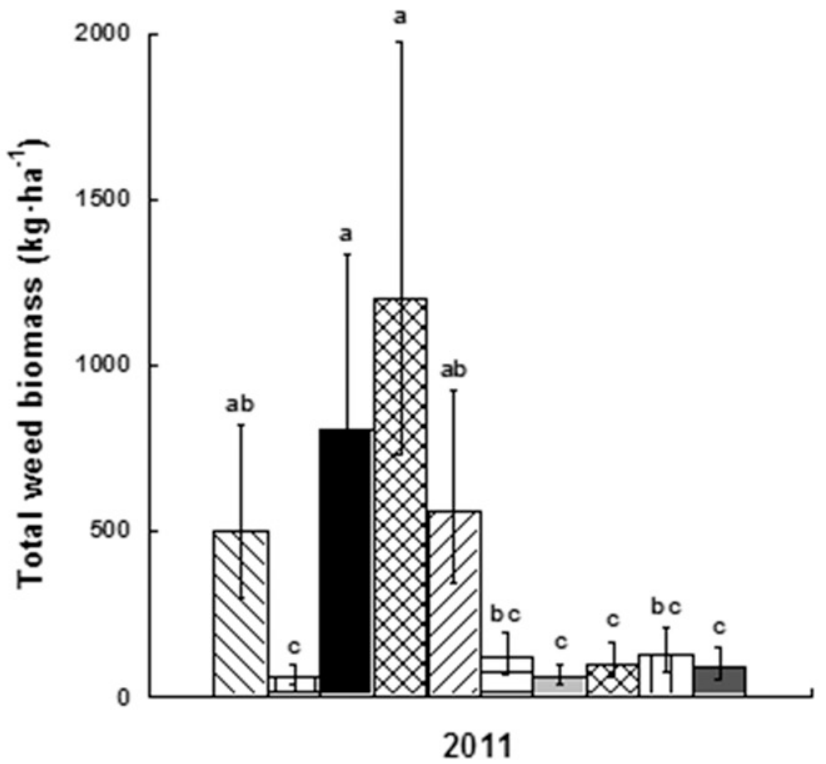

(B)

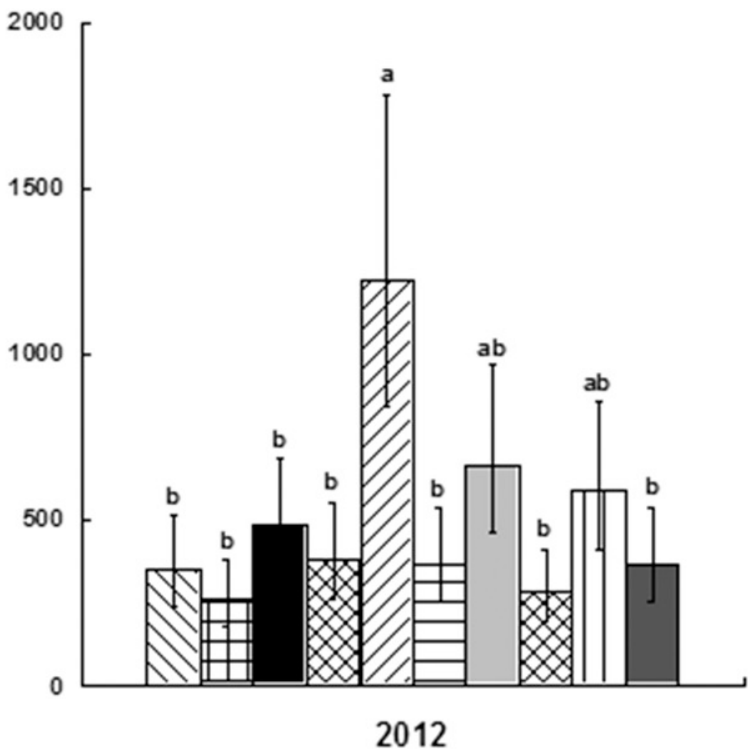

Fig. 2. Least squares means and ses of total aboveground weed biomass for each monoculture and intercropping combination in (A) 2011 and (B) 2012 [ $W_{\mathrm{pw}}=$ within-row intercropping of peanut-watermelon; $S_{\mathrm{pw}}=$ strip intercropping with peanutwatermelon (e.g., alternating rows); $W_{\mathrm{pwo}}=$ within-row intercropping of peanut-watermelon-okra; $W_{\mathrm{pwoc}}=$ within-row intercropping of peanut-watermelon-okra-cowpea; and $W_{\text {all }}=$ within-row intercropping of peanut-watermelon-okracowpea-pepper]. Different letters indicate statistically significant differences $(P \leq 0.05)$ between means within years according to Fisher's least significant difference test; $1 \mathrm{~kg} \cdot \mathrm{ha}^{-1}=0.8922 \mathrm{lb} /$ acre.

watermelon as a smother crop. Although there is plentiful information on ability of cover crops to reduce weeds in the literature (Lu et al., 2000; Mulvaney et al., 2011), we were unable to find literature on the utilization of a cucurbit cash crop to make direct comparisons with. However, in a study of other vegetable crops, MoralesPayan et al. (1997) found that compared with bell pepper, tomato (Solanum lycopersicum) reduced nutsedge biomass more effectively, likely because of differences in canopy density and structure between the two crops.

In 2012, the nutsedges were the only weed type effectively suppressed and accounted for most of the weed biomass in pepper monoculture, the cropping system with significantly higher weed biomass. Purple and yellow nutsedge pose a particular challenge to organic producers because of their ability to reproduce vigorously, competitive $C_{4}$ photosynthetic efficiency, widespread distribution, and difficulty to control (Morales-Payan et al., 2003; Schroeder et al., 1999; Wang et al., 2009; Williams, 1982). In a competition study conducted in
Brazil, researchers found that purple nutsedge reduced yields of okra and cucumber (Cucumis satipus), a crop with similar growth form as watermelon, by as much as $62 \%$ and $43 \%$, respectively (William and Warren, 1975). They also found that the critical period for nutsedge control was 3 and 7 weeks for both crops. Yields of bell pepper, a slow-growing crop similar to pepper used in this study, can be reduced by as much as $32 \%$ because of competition with nutsedge (MoralesPayan et al., 1997). However, both purple and yellow nutsedge have been shown to respond to shading by reducing dry matter as well as tuber production (Patterson, 1982). Morales-Payan et al. (2003) found that tomato shading exerted a stronger influence on purple nutsedge growth than did belowground competition for nutrients.

In an intercropping study with leek (Allium porrum) and celery (Apium graveolens), it was found that increased canopy cover and light interception as a result of intercropping effectively suppressed weeds (Baumann et al., 2001). The negative relationship between total aboveground plant biomass, as a proxy for canopy cover, and weed biomass, although not a strong one, appeared to support the idea that high canopy cover can suppress weed growth in this study. One possible explanation for why this relationship was not as strong as hypothesized has to do with the change in crop dominance between years. Data on aboveground plant biomass were only collected in 2012 when the weed suppressive effects of watermelon were drastically reduced and when okra was dominant. When conditions favored okra growth and watermelon was adversely affected by disease, the results of the plant biomass-weed biomass relationship may have been skewed by the high amount of lignified stem material in okra. Had leaf material been collected separately and regressed against total weed biomass, it is possible that this relationship would have been stronger. Nonetheless, it is likely that aboveground competition for space and increased shading caused by watermelon canopy in 2011 and by the dense canopy created by all component crops in 


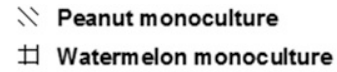

(A)

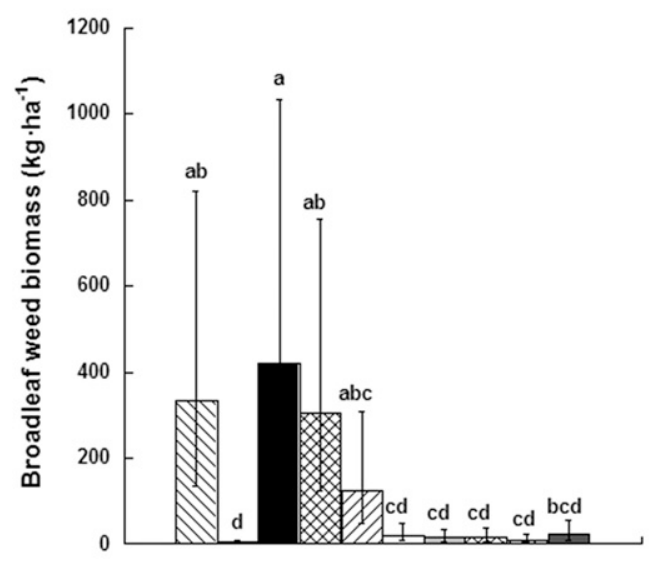

(C)

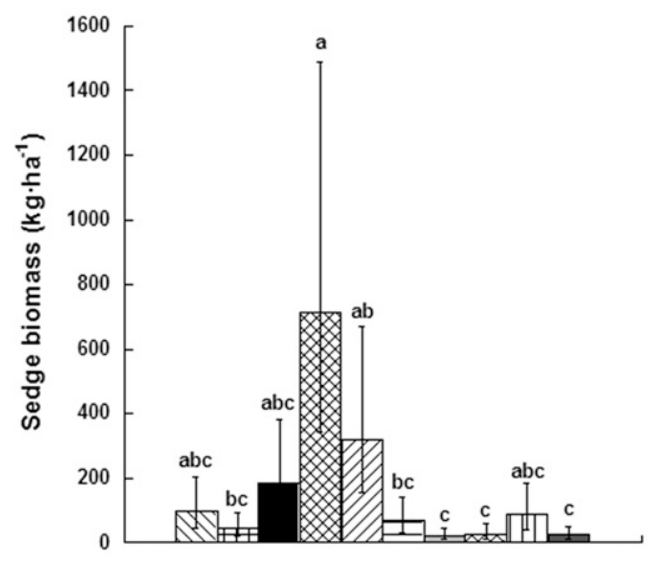

(E)

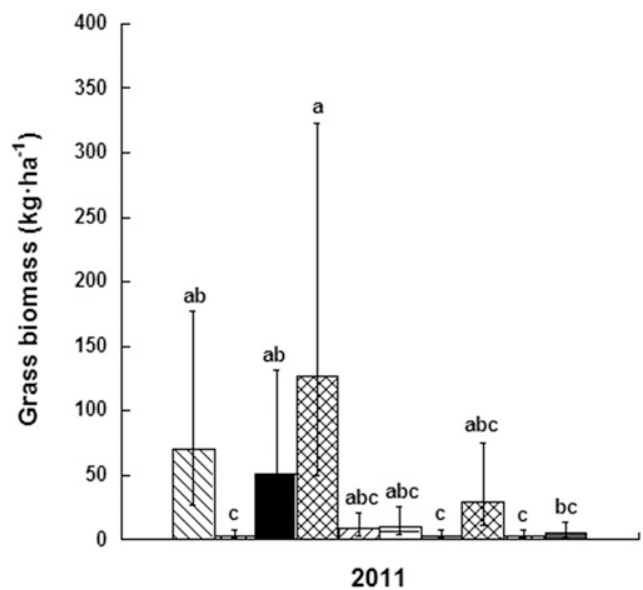

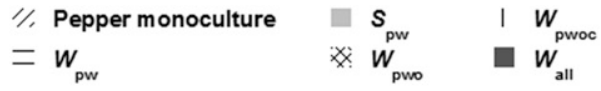

(B)

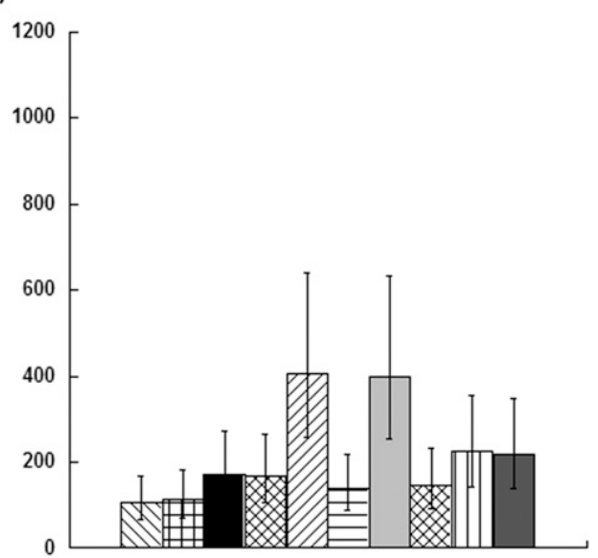

(D)

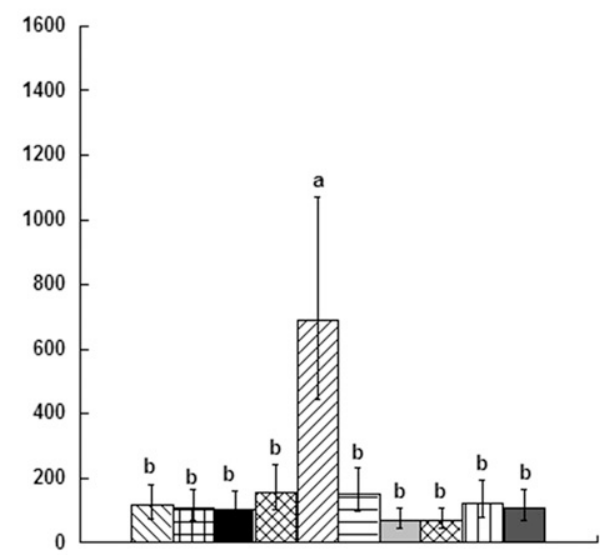

(F)

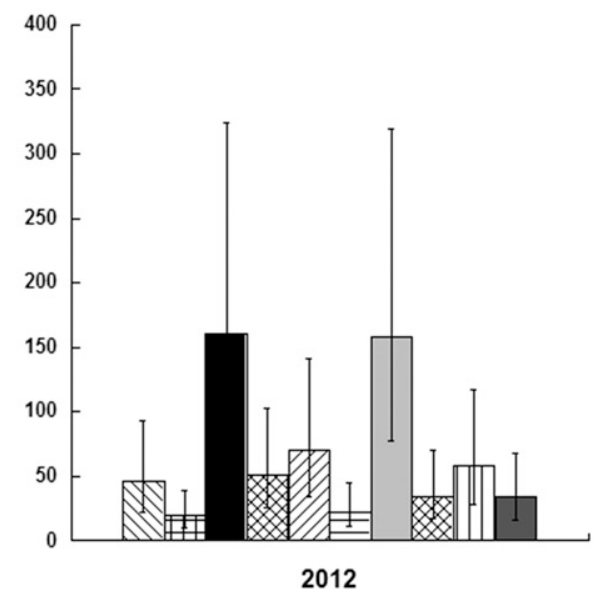

Fig. 3. Least squares means and standard errors of the mean of aboveground (A and B) broadleaf, (C and D) sedge, and (E and F) grass weed biomass for each monoculture and intercropping combination in 2011 and 2012, respectively [ $W_{\mathrm{pw}}=$ within-row intercropping of peanut-watermelon; $S_{\mathrm{pw}}=$ strip intercropping with peanut-watermelon (e.g., alternating rows); $W_{\text {pwo }}=$ within-row intercropping of peanut-watermelon-okra; $W_{\text {pwoc }}=$ within-row intercropping of peanut-watermelon-okracowpea; and $W_{\text {all }}=$ within-row intercropping of peanut-watermelon-okra-cowpea-pepper]. The most prevalent broadleaf weeds were carpetweed, common purslane, and spurge (data not shown). The most prevalent sedges were yellow and purple nutsedge (data now shown), and the most prevalent weedy grasses were crabgrass and bermudagrass (data not shown). Different letters indicate statistically significant differences $(P \leq 0.05)$ between means within years according to Fisher's least significant difference test; $1 \mathrm{~kg} \cdot \mathrm{ha}^{-1}=0.8922 \mathrm{lb} / \mathrm{acre}$. 
(A)

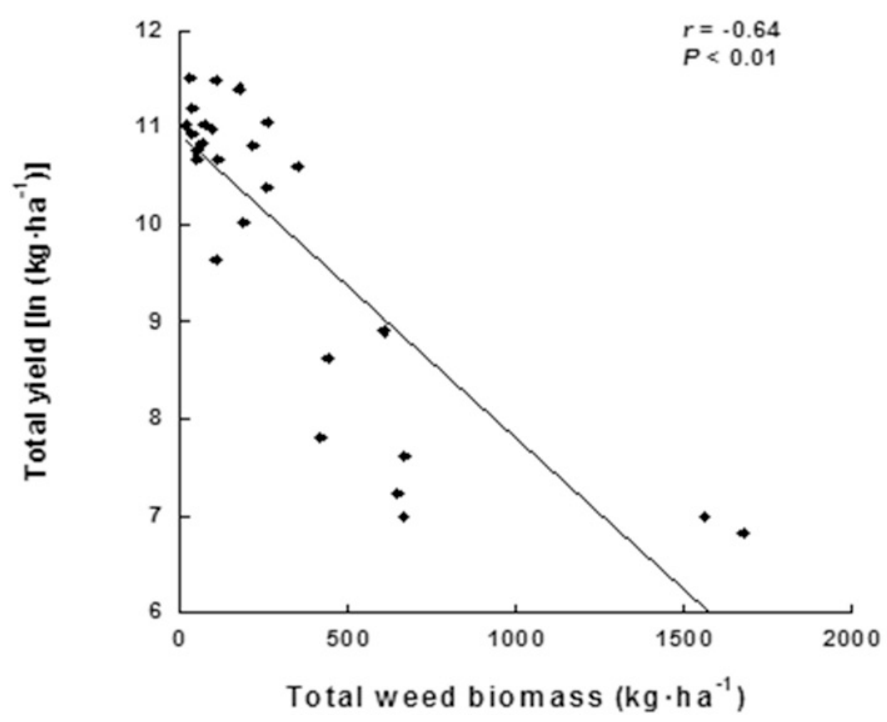

(B)

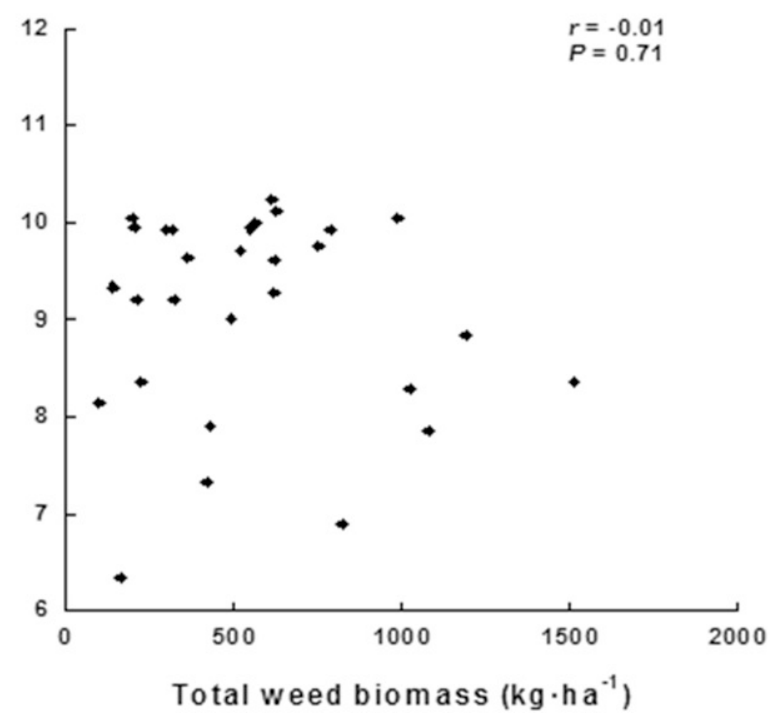

Fig. 4. Relationship between total aboveground weed biomass and natural log-transformed total plot yield in (A) 2011 and (B) 2012 across all intercropping and monocropping systems. There was a significant $(P \leq 0.05)$ negative relationship between weed biomass and total plot yield in 2011 but no significant relationship in $2012 ; 1 \mathrm{~kg} \cdot \mathrm{ha}^{-1}=0.8922 \mathrm{lb} / \mathrm{acre}$.

(A)

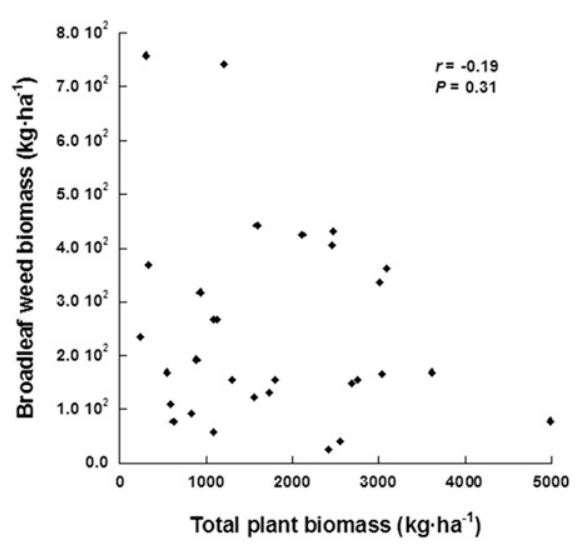

(B)

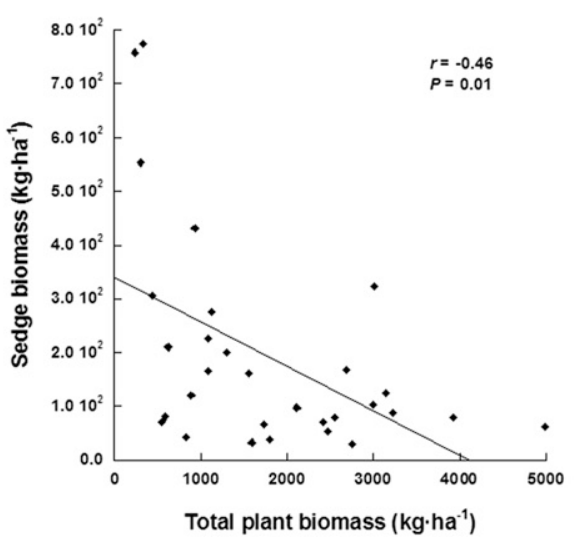

(C)

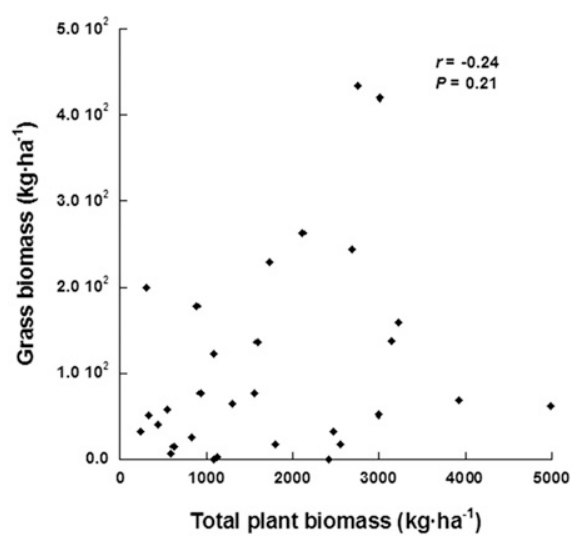

Fig. 5. Relationship between total aboveground cash crop plant biomass and aboveground (A) broadleaf weed biomass, (B) sedge weed biomass, and (C) grass weed biomass in 2012 . There was a significant $(P \leq 0.05)$ negative relationship between total plant biomass and sedge weed biomass; $1 \mathrm{~kg} \cdot \mathrm{ha}^{-1}=0.8922 \mathrm{lb} / \mathrm{acre}$.

2012 led to less available light for weed populations as suggested by the negative linear relationship found between LAI and total weed biomass as well as findings by other authors (Baumann et al., 2002; Saudy, 2015; Steinmaus et al., 2008). In this study, pepper had significantly smaller leaf area and reduced plant biomass as compared with other crops used in this study and as compared with all intercropping combinations. This resulted in significantly greater total weed biomass in 2011 and greater sedge weed biomass in 2012 in pepper monoculture. Having characteristically large leaves, okra monoculture and those combinations, including okra, $W_{\text {pwo }}$, and $W_{\text {pwoc }}$, had some of the largest LAI values $(>2.0)$ in 2012. In other studies, cash crops that have successfully outcompeted weeds had characteristically high LAI and biomass early in the growing season (Callaway, 1992; Wortman, 1993), resulting in not only less light but also lower quality light [i.e., low red:far red ratio (Buhler, 2003)]. The introduction of a crop with a small leaf area such as pepper in the five species combination, $W_{\text {all }}$, reduced LAI values in 2012 .

Correlation analyses indicated a strong relationship between weed biomass, in particular, sedge and grass biomass, and total yield in 2011 . In other studies on vegetable crops and on peanut, yields decreased as the time of weed interference with the cash crop increased (Weaver, 1984; Zimdahl, 2004). Weaver and Tan (1987) found that weed dry weight was inversely correlated with tomato yields, similar to our findings. Clark et al. (1998) reported a correlation 

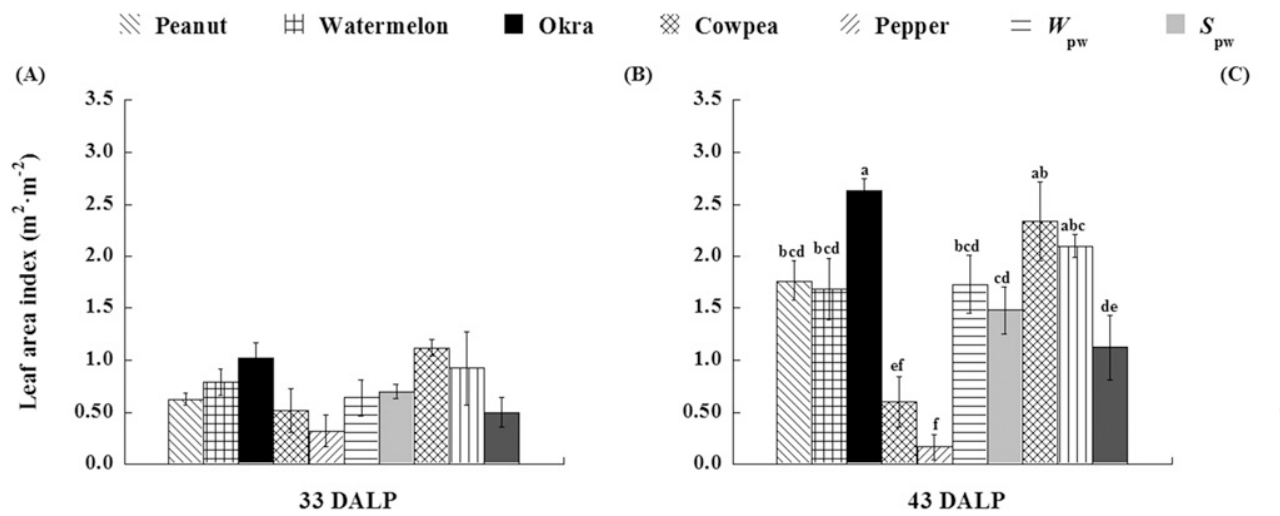

43 DALP

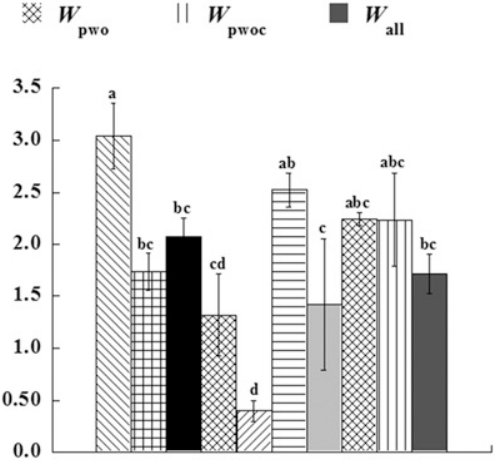

63 DALP

Fig. 6. Leaf area index [leaf area index (square meters leaf area per square meter soil surface)] of monoculture controls and intercropping treatments taken (A) $33 \mathrm{~d}$ after last planting (DALP), (B) 43 DALP, and (C) 63 DALP in 2012 [ $W_{\mathrm{pw}}=$ withinrow intercropping of peanut-watermelon; $S_{\mathrm{pw}}=$ strip intercropping with peanut-watermelon (e.g., alternating rows); $W_{\mathrm{pwo}}=$ within-row intercropping of peanut-watermelon-okra; $W_{\text {pwoc }}=$ within-row intercropping of peanut-watermelon-okracowpea; and $W_{\text {all }}=$ within-row intercropping of peanut-watermelon-okra-cowpea-pepper]. Different letters indicate statistically significant differences $(P \leq 0.05)$ between means within dates according to Fisher's least significant difference test; $1 \mathrm{~m}^{2}=10.7639 \mathrm{ft}^{2}$.

(A)

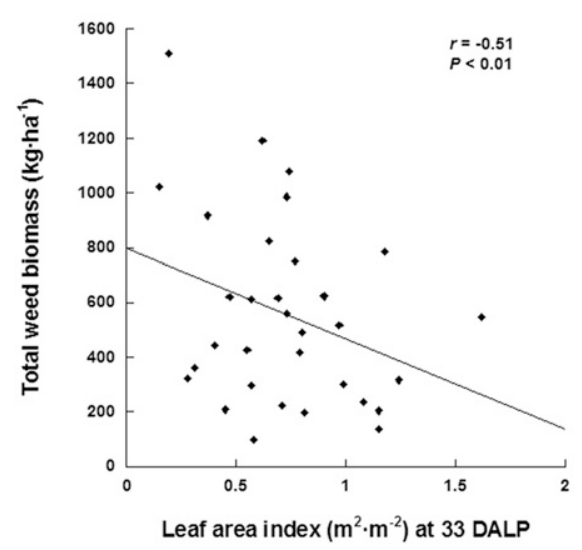

(B)

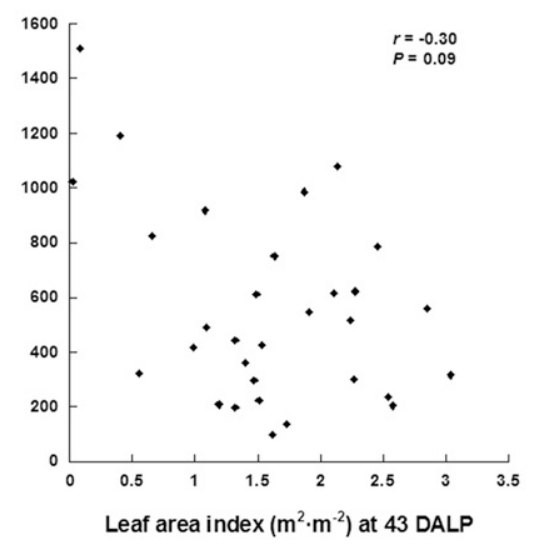

(C)

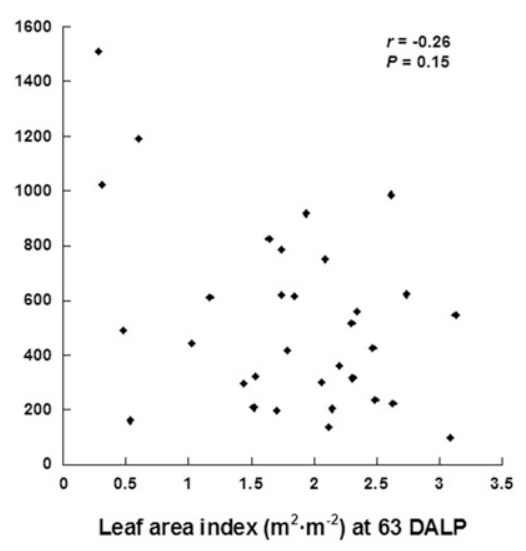

Fig. 7. Relationship between leaf area index [leaf area index (square meters leaf area per square meter soil surface)] at three times during the season and total aboveground weed biomass produced throughout the season at (A) $33 \mathrm{~d}$ after last planting (DALP), (B) 43 DALP, and (C) 63 DALP. There were significant $(P \leq 0.05)$ negative relationships between LAI and total weed biomass 33 DALP; $1 \mathrm{~m}^{2}=10.7639 \mathrm{ft}^{2}, 1 \mathrm{~kg} \cdot \mathrm{ha}^{-1}=0.8922 \mathrm{lb} /$ acre.

coefficient of $r=-0.31 \quad(P<0.01)$ when weed biomass and tomato yield were compared. In a study on rice (Oryza sativa), a negative relationship was observed between weed biomass and crop yield with correlation coefficients ranging from $r=-0.48$ to $-0.59[P=0.01$ (Garrity et al., 1992)]. In this study, correlation coefficients found between total yield and grass weed and total yield and sedge weed biomass were comparable if not higher than those reported in other studies. In 2012, there was a significant negative relationship between nutsedge biomass and total plant biomass. William and Warren (1975) found yield reductions ranging from $35 \%$ to $89 \%$ in vegetable crops due to purple nutsedge pressure alone.

In examining the factors driving the competitive relationship between weeds and crops, competition for light and water are considered two of the most important (Weaver and Tan, 1987). It is also plausible that more efficient use of belowground resources such as water and nutrients due to enhanced niche differentiation by multiple species (Tilman, 2001) and possible allelopathic effects from watermelon root exudates (Hao et al., 2007; Yun et al., 2000) may have further reduced the competitive ability of weeds (Singh et al., 2010; Weston and Duke, 2003) in intercropping treatments. However, these are parameters that were not measured and are beyond the scope of this study.

Results from both years suggested that incorporating a multifunctional intercropping system that includes a low-growing vining crop such as watermelon or at least an architecturally complex mixture can optimize canopy density to reduce weed pressure from resilient weeds such as nutsedge in organic systems. This may offer producers another management tool for the control of perennial weeds, particularly those producers who are hesitant to transition to organic production because of the difficulty of managing perennial weeds (Wedryk et al., 2012). In addition, this 
cultural approach to weed management may offer a higher economic return than other weed control strategies such as cover crops, cultivation, and solarization (Wang et al., 2009) due to the value-added production of watermelon and other cash crops. Further value is added with the reduction in manual labor and its associated high cost (den Hollander et al., 2007; Weston and Duke, 2003). However, it is unknown if the benefits of reducing weed competition outweigh the competitive interactions between component crops. In addition, a limitation of intercropping is an increase in the management complexity associated with planting and harvesting. However, proper planning can circumvent those issues. Combined with our yield findings that we previously reported (Franco et al., 2015), we conclude that three and four functionally diverse species combinations appear to offer the most promise for organic producers who want to suppress weeds naturally without the associated labor inputs, while maximizing total yields on a per area basis. In particular, this offers a promising management tool for organic producers for the control of perennial nutsedges which are known to cause significant yield losses.

\section{Literature cited}

Akobundu, I.O. 1987. Weed science in the tropics: Principles and practices. Wiley, New York, NY.

Barberi, P. 2002. Weed management in organic agriculture: Are we addressing the right questions? Weed Res. 42:177193.

Baughman, T., P. Dotray, J. Grichar, M. Black, J. Woodward, C. Trostle, S. Russell, C. Crumley, P. Porter, L. New, P. Baumann, and M. McFarland. 2007. Texas peanut production guide. Texas Coop. Ext. Serv., College Station, TX.

Baumann, D.T., L. Bastiaans, J. Goudriaan, H.H. van Laar, and M.J. Kropff. 2002. Analysing crop yield and plant quality in an intercropping system using an ecophysiological model for interplant competition. Agr. Syst. 73:173-203.

Baumann, D.T., L. Bastiaans, and M.J. Kropff. 2001. Competition and crop performance in a leek-celery intercropping system. Crop Sci. 41:764-774.

Bilalis, D., P. Papastylianou, A. Konstantas, S. Patsiali, A. Karkanis, and A. Efthimiadou.
2010. Weed-suppressive effects of maizelegume intercropping in organic farming. Intl. J. Pest Mgt. 56:173-181.

Buhler, D.D. 2003. Weed biology, cropping systems, and weed management. J. Crop Prod. 8:245-270.

Callaway, M.B. 1992. A compendium of crop varietal tolerance to weeds. Amer. J. Altern. Agr. 7:169-180.

Clark, M.S., H. Ferris, K. Klonsky, W.T. Lanini, A.H.C. van Bruggen, and F.G. Zalom. 1998. Agronomic, economic, and environmental comparison of pest management in conventional and alternative tomato and corn systems in northern California. Agr. Ecosyst. Environ. 68:51-71.

Dayan, F.E., C.L. Cantrell, and S.O. Duke. 2009. Natural products in crop protection. Bioorg. Med. Chem. 17:4022-4034.

Dayan, F.E., J.L. Howell, J.P. Marais, D. Ferreira, and M. Koivunen. 2011. Manuka oil: A natural herbicide with preemergence activity. Weed Sci. 59:464-469.

den Hollander, N.G., L. Bastiaans, and M.J. Kropff. 2007. Clover as a cover crop for weed suppression in an intercropping design: I. Characteristics of several clover species. Eur. J. Agron. 26:92-103.

Denevan, W.M. 1995. 2 Prehistoric agricultural methods as models for sustainability. Adv. Plant Pathol. 11:21-43.

Franco, J.G., S.R. King, J.G. Masabni, and A. Volder. 2015. Plant functional diversity improves short-term yields in a low-input intercropping system. Agr. Ecosyst. Environ. 203:1-10.

Garrity, D.P., M. Movillon, and K. Moody. 1992. Differential weed suppression ability in upland rice cultivars. Agron. J. 84:586-591.

Hao, Z.P., Q. Wang, P. Christie, and X.L. Li. 2007. Allelopathic potential of watermelon tissues and root exudates. Scientia Hort. 112:315-320.

Iqbal, J., Z.A. Cheem, and M. An. 2007. Intercropping of field crops in cotton for the management of purple nutsedge (Cyperus rotundus L.). Plant Soil 300: 163-171.

Isik, D., E. Kaya, M. Ngouajio, and H. Mennan. 2009. Weed suppression in organic pepper (Capsicum annuum L.) with winter cover crops. Crop Protection 28: 356-363.

Jeavons, J. 2006. How to grow more vegetables (and fruits, nuts, berries, grains, and other crops) than you ever thought possible on less land than you can imagine. Ten Speed Press, Berkeley, CA.
Karlen, D.L., D.D. Buhler, M.M. Elisbury, and S.S. Andrews. 2002. Soil weed and insect management strategies for sustainable agriculture. J. Biol. Sci. 2:58-62.

Keating, B.A. and P.S. Carberry. 1993. Resource capture and use in intercropping: Solar radiation. Field Crops Res. 34:273-301.

Kiniry, J.R., C.E. Simpson, A.M. Schubert, and J.D. Reed. 2005. Peanut leaf area index, light interception, radiation use efficiency, and harvest index at three sites in Texas. Field Crops Res. 91:297-306.

Lu, Y-C., B. Watkins, J.R. Teasdale, and A.A. Abdul-Baki. 2000. Cover crops in sustainable food production. Food Rev. Intl. 16:121-157.

Masabni, J.G. and F.J. Dainello. 2009. Texas vegetable growers handbook. Texas A\&M AgriLife Ext. Serv., College Station, TX.

Miller, J.C., Jr., and D.C. Scheuring. 1994. Texas pinkeye purple hull cowpea. HortScience 29:926-927.

Mohler, C.L. and K.A. Stoner. 2009. Guidelines for intercropping, p. 95-100. In: C.L. Mohler and S.E. Johnson (eds.). Crop rotation on organic farms: A planning manual. Natural Resource, Agriculture, and Engineering Service NRAES-177.

Morales-Payan, J.P., B.M. Santos, W.M. Stall, and T.A. Bewick. 1997. Effects of purple nutsedge (Cyperus rotundus) on tomato (Lycopersicon esculentum) and bell pepper (Capsicum annuum) vegetative growth and fruit yield. Weed Technol. 11:672-676.

Morales-Payan, J.P., W.M. Stall, D.G. Shilling, R. Charudattan, J.A. Dusky, and T.A. Bewick. 2003. Above- and belowground interference of purple and yellow nutsedge (Cyperus spp.) with tomato. Weed Sci. 51:181-185.

Mulvaney, M.J., A.J. Price, and C.W. Wood. 2011. Cover crop residue and organic mulches provide weed control during limited-input no-till collard production. J. Sustain. Agr. 35:312-328.

National Oceanic and Atmospheric Administration. 2018. Climate data online. 15 Feb. 2018. <https://www.ncdc.noaa.gov/ cdo-web/search?datasetid=GHCND $>$.

Patterson, D.T. 1982. Shading responses of purple and yellow nutsedges (Cyperus rotundus and C. esculentus). Weed Sci. 30:25-30.

Peruzzi, A., M. Ginanni, M. Fontanelli, M. Raffaelli, and P. Barberi. 2007. Innovative strategies for on-farm weed management in organic carrot. Renew. Agr. Food Syst. 22:246-259. 
Saudy, H.S. 2015. Maize-cowpea intercropping as an ecological approach for nitrogen-use rationalization and weed suppression. Arch. Agron. Soil Sci. 61:1-14.

Schieving, F. and H. Poorter. 1999. Carbon gain in a multispecies canopy: The role of specific leaf area and photosynthetic nitrogen-use efficiency in the tragedy of the commons. New Phytol. 143:201-211.

Schroeder, J., S.H. Thomas, and L.W. Murray. 1999. Yellow (Cyperus esculentus) and purple nutsedge (Cyperus rotundus) are not injured by increasing root-knot nematode (Meloidogyne incognita) population density. Weed Sci. 47:201-207.

Singh, S., G. Ghosh, and S. Elamathi. 2010. Production potential and economics of baby corn (Zea mays) and cowpea (Vigna unguiculata) intercropping as influenced by different row ratios under organic farming condition. Natl. Acad. Sci. Lett. 33:5.

Steinmaus, S., C.L. Elmore, R.J. Smith, D. Donaldson, E.A. Webber, J.A. Roncoroni, and P.R.M. Miller. 2008. Mulched cover crops as an alternative to conventional weed management systems in vineyards. Weed Res. 48:273-281.
Tilman, D. 2001. An evolutionary approach to ecosystem functioning. Proc. Natl. Acad. Sci. USA 98:1097910980.

Unlu, H., N. Sari, and I. Solmaz. 2010. Intercropping effect of different vegetables on yield and some agronomic properties. J. Food Agr. Environ. 8:723-727.

Vandermeer, J.H. 1989. The ecology of intercropping. Cambridge Univ. Press, New York, NY.

Wang, G., M.E. McGiffen, E.J. Ogbuchiekwe, and L. Butler. 2009. Economic return of purple and yellow nutsedge management in vegetable production of southern California. Crop Protection 28:319-326.

Weaver, S.E. 1984. Critical period of weed competition in three vegetable crops in relation to management practices. Weed Res. 24:317-325.

Weaver, S.E. and C.S. Tan. 1987. Critical period of weed interference in fieldseeded tomatoes and its relation to water stress and shading. Can. J. Plant Sci. 67:575-583.

Webber, C.L., III., M.J. Taylor, and J.W. Shrefler. 2014. Weed control in yellow squash using sequential postdirected applications of pelargonic acid. HortTechnology 24:25-29.
Wedryk, S., J. Felix, D. Doohan, and J. Cardina. 2012. Strategies for weed suppression and improving soil fertility during transition to organic vegetable production. HortTechnology 22:207214.

Weston, L.A. and S.O. Duke. 2003. Weed and crop allelopathy. Crit. Rev. Plant Sci. 22:367-389.

Williams, R.D. 1982. Growth and reproduction of Cyperus esculentus L. and Cyperus rotundus L. Weed Res. 22:149154.

William, R.D. and G.F. Warren. 1975. Competition beween purple nutsedge and vegetables. Weed Sci. 23:317-323.

Wortman, C.S. 1993. Contribution of bean morphological characteristics to weed suppression. Agron. J. 85:840-843.

Yun, J.Q., S.Y. Shou, Y.R. Qian, Z.J. Zhu, and W.H. Hu. 2000. Autotoxic potential of cucurbit crops. Plant Soil 223:147151 .

Zimdahl, R.L. 2004. Weed-crop competition: A review. 2nd ed. Blackwell Publ., Oxford, UK. 